\title{
Altering Condensate Levels in Tobacco Smoke by Genetic Techniques*
}

by

\author{
James F. Chaplin
}

Tobacco Researd Laboratory, Agricultural Research Service, United States Department of Agriculture, Oxford, N.C., U.S.A., and Department of Crop Science, North Carolina State University, Raleigh, North Carolina, U.S.A.

and

Harvey W. Spurr, Jr.

Tobacco Researdh Laboratory, Agricultural Researd Service, United States Department of Agriculture, Oxford, N.C., U.S.A.; and Department of Plant Patbology, North Carolina State University, Raleigh, North Carolina, U.S.A.

\section{INTRODUCTION}

Lower levels of condensate in cigarette smoke are being sought in various ways. Manufacturers can lower condensate but most of the methods used lower smoke nicotine and other smoke constituents simultaneously. Tobacco breeders are attempting to develop lines of tobacco - whose cured leaf, upon pyrolysis, delivers less condensate in the smoke. Condensate is defined by the Federal Trade Commission (FTC) as total particulate matter collected on a standard Cambridge filter pad, after cigarettes have been smoked under specific conditions, minus nicotine and water. Condensate consists of many constituents and would appear to be difficult to dhange through genetic manipulations. Russell (11) suggested that we should aim toward lowering the yield of constituents suh as condensate, carbon monoxide and others, without a concomitant lowering of nicotine. According to his suggestion, if this were accomplished the smoker would not consume more cigarettes to compensate for the low delivery of nicotine from low-condensate-low-nicotine cigarettes. Hence the condensate : nicotine ratio may be important in developing lines of tobacco that will deliver lower levels of condensate on pyrolysis. It has come to the attention of the authors that Russell and other investigators have somewhat changed their viewpoint on reducing condensate but not nicotine when they found that cigarettes, whose smoke showed a condensate to nicotine ratio less than 8 or 9 , were rejected by consumers.

The purpose of this paper was to review the researction breeding for varying levels of condensate delivery, to present data from our own research, and to make suggestions for future attemps to develop tobaccos that de-

\footnotetext{
- Presented at the 7 th International Tobacco Scientific Congress (Coresta) held in Mazila, The Philippines, in 1980.

Received: 30th March 1981 - accepted: 9th November 1981.
}

liver low condensate or that deliver smoke with a lower condensate : nicotine ratio.

Matzinger and Wernsman (7) studied certain smoke constituents delivered by a synthetic population of eight commercial cultivars of flue-cured tobacco. They showed significant genetic variations for cigarette weight, total alkaloids, puff/cigarette, wet total particulate matter (WTPM)/cigarette, and WTPM/puff. WTPM ranged from 25.2 to $36.6 \mathrm{mg} /$ cigarette. They concluded that changes in total particulate matter (TPM) could be accomplished by breeding.

In attempting to develop lines of tobacco that yield low condensate, a large number of samples have to be assayed. This is difficult with the FTC condensate method because it requires samples which contain relatively large quantities of tobacco. Long and Wilson (6) described a procedure to estimate the particulate matter of cigarettes by pyrolyzing a 1 gram sample of tobacco. Therefore, by using the particulate matter index (PMI) technique, it is possible to analyze a large number of samples. Wernsman et al. (13) reported that PMI of 120 random $F_{5}$ lines from a Hicks $\times$ Coker $139 F_{1}$ ranged from 174 to $226 \mathrm{mg} / \mathrm{g}$. Estimated PMI reduction in the next generation, obtained by selecting the lowest $8.3 \%$ of lines in the population, was $10.2 \mathrm{mg} / \mathrm{g}$ or $5.1 \%$ of the population mean. Later, Matzinger et al. (8) reported that selection of PMI within a bladk shank-resistant synthetic population for reduced particulate matter in tobacco smoke was effective in obtaining a population which produced $14.3 \%$ less PMI after three cycles of recurrent mass selection:. This selection also lowered FIC condensate, but to a lesser extent. They also concluded from their study that selection for lower PMI would also lower leaf and smoke nicotine. Preliminary results indicate that selection for higher levels of nicotine and lower PMI can be accomplished if selections for both constituents are made concomitantly. 
Davis et al. (3) compared the PMI to cigarette condensate values for certain Burley tobacco genotypes and found that the ranking of genotypes was not the same for both methods; thus the two methods may not be comparable.

Data from experiments conducted at Oxford, N. C., in a program to develop tobaccos with lower condensate delivery, are presented in this paper.

\section{MATERIALS AND ME'THODS}

\section{Cigarette Fabrication and Condensate Collection}

After the tobacco was flue-cured, all of the primings from a plant were combined so each sample represented all of the tobacco produced on the plant. The tobacco was stemmed and the lamina made into $85 \mathrm{~mm}$ non-filter cigarettes. The cigarettes were selected for weight and constant draw pressure $(7.5 \mathrm{~cm} \mathrm{Hg})$ at a flow rate of $17.5 \mathrm{~cm} / \mathrm{s}$ and kept at a constant relative humidity, $60 \%$, and temperature, $23.9^{\circ} \mathrm{C}$. The weights of the cigarettes varied among the samples; however, the weights of all cigarettes within a sample were constant. For each sample, 40 cigarettes were smoked on a 20-port Phipps and Bird smoking machine*, under standard conditions, to a $23 \mathrm{~mm}$ butt length as described by Pillsbury et al. (9) and the wet particulate matter was collected on 10 Cambridge filters ( 4 cigarettes per filter).

\section{Cigarette Characterization}

Data on a cigarette basis were obtained for weight, total particulate matter, nicotine, water, and puff count. Condensate delivery values per cigarette were calculated by subtracting nicotine and water from total particulate matter. The condensate / $g$ of tobacco smoked was based on the amount of tobacco in the $62 \mathrm{~mm}$ portion of the cigarette actually smoked. Water and nicotine in total particulare matter were determined by the methods of Watson et al. (12) and Randolph (10), respectively.

\section{Procedure for}

\section{Particulate Matter Index (PMI) Determination}

The procedure for PMI determination was a modification of that reported by Long and Wilson (6). The cured leaf was stemmed, dried for approximately $48 \mathrm{~h}$ at $65^{\circ} \mathrm{C}$, and conditioned at approximately $21^{\circ} \mathrm{C}$ and $60 \%$ relative humidity for grinding. The samples were ground in a Wiley Mill* through a $2 \mathrm{~mm}$ screen. The ground samples were sieved through two screens: a coarse screen with an 850-micron mesh and a fine screen with a 500micron mesh. The tobacco passing through the coarse screen and retained on the fine screen was used for the PMI determination. The ground and sized samples were brought to moisture equilibrium at $21.1^{\circ} \mathrm{C}$ and $60 \%$

\footnotetext{
- Reference to a company or produce name does noe imply approval or recommendation by the United States Department of Agriculture.
}

relative humidity in a constant temperature - relative humidity room. A $1 \mathrm{~g}$ sample of tobacco was placed in a Pyrex combustion tube. A pre-weighed Cambridge filter holder and pad were attached to the combustion tube and connected to a vacuum. The combustion tube was placed in a furnace at $620^{\circ} \mathrm{C}$. The Cambridge filter holder and pad were reweighed and the weight increase following pyrolysis was used as the PMI. Duplicate particulate matter indices (PMI) were determined for each sample. The remaining tobacco from each sample was redried, reground and analyzed for total alkaloids by the Griffith procedure (4).

\section{RESULTS AND DISCUSSION}

Data are presented by experiments because it is invalid to compare data from one experiment with another since condensate and nicotine deliveries are considerably altered by the weather and cultural conditions to which the tobaccos were exposed.

\section{Condensate Delivery Levels from \\ U.S. Flue-cured cultivars}

Samples of tobacco cultivars from three locations in North Carolina (2 replicates at each location) were obtained which represented most of the flue-cured cultivars currently grown in the United States (Table 1). The condensate deliveries from flue-cured cultivars ranged from 23.9 to $31.5 \mathrm{mg} / \mathrm{cig}$. and from 26.8 to $32.9 \mathrm{mg} / \mathrm{g}$ of tobacco smoked. Condensate : nicotine ratios ranged from 5.9 to 7.9 . This narrow range was understandable because all flue-cured tobacco cultivars in the United States meet minimum standards before release. These standards include nicotine levels, hence most flue-cured cultivars have similar levels. There was a wide range in condensate/cigarette but the range for condensate / $g$ of tobacco smoked was much narrower. Wernsman et al. (13) reported PMI averages for 10 flue-cured cultivars and stated that differences among those cultivars for PMI were small. They concluded that shifts in popularity among cultivars by growers would not drastically change the TPM potential of cured leaf available to manufacturers. They also gave data from a large number of cultivars and classes of tobacco which showed that PMI means were highest for Burley cultivars, followed by dark fire-cured, air-cured, flue-cured, and Maryland cultivars.

\section{Condensate Delivery from Old Lines of Flue-cured, Burley and other Cultivars}

Twenty-two cultivars, Tobacco Introductions (TI), and breeding lines were planted in a randomized block design for 2 years at Oxford, N.C. The tobacco was grown and cured as flue-cured tobacco.

The condensate deliveries ranged from $19.7 \mathrm{mg} / \mathrm{cig}$. (Hidks-Mammoth) to 35.8 (TI 1335) (Table 2). Con- 
Table 1. Condensate and nicotine from commercial fluecured tobacco cultivars (average of three locations in North Carolina - 1976).

\begin{tabular}{|c|c|c|c|c|}
\hline Cultivar & $\begin{array}{c}\text { Nicotine / } \\
\text { cigarette } \\
\text { (mg) }\end{array}$ & $\begin{array}{c}\text { Conden- } \\
\text { sate* / } \\
\text { cigarette } \\
(\mathrm{mg})\end{array}$ & $\begin{array}{c}\text { Conden- } \\
\text { sate / g of } \\
\text { tobacco } \\
\text { smoked"* } \\
\text { (mg) }\end{array}$ & $\begin{array}{l}\text { Conden- } \\
\text { sate: nic- } \\
\text { otine }\end{array}$ \\
\hline NC 79 & 4.0 & 31.5 & 31.0 & 7.9 \\
\hline Coker 347 & 4.0 & 30.8 & 32.9 & 7.7 \\
\hline McNair 1040 & 3.9 & 29.7 & 31.4 & 7.6 \\
\hline NC 2326 & 3.7 & 28.5 & 30.8 & 7.7 \\
\hline Speight G-140 & 3.5 & 27.5 & 30.6 & 7.9 \\
\hline McNair 944 & 3.5 & 27.3 & 29.0 & 7.8 \\
\hline NC 12 & 3.8 & 27.1 & 30.0 & 7.1 \\
\hline Speight G-23 & 4.0 & 27.0 & 30.1 & 6.8 \\
\hline Va. 115 & 3.8 & 26.8 & 31.3 & 7.1 \\
\hline NC 88 & 4.2 & 26.8 & 29.7 & 6.4 \\
\hline Coker 298 & 3.8 & 26.7 & 30.3 & 7.0 \\
\hline Coker 254 & 3.7 & 26.1 & 29.1 & 7.1 \\
\hline Coker 319 & 3.4 & 26.1 & 31.1 & 7.7 \\
\hline Coker 411 & 3.7 & 25.9 & 30.3 & 7.0 \\
\hline NC 98 & 3.6 & 25.7 & 28.3 & 7.1 \\
\hline NC 95 & 4.1 & 25.7 & 30.6 & 6.3 \\
\hline Speight G-33 & 3.9 & 25.5 & 27.7 & 6.5 \\
\hline Speight G-15 & 4.3 & 25.3 & 29.4 & 5.9 \\
\hline Coker 258 & 4.0 & 24.9 & 29.3 & 6.2 \\
\hline Speight G-28 & 3.3 & 23.9 & 26.8 & 7.2 \\
\hline $\left.\begin{array}{l}\text { Least sig- } p=0.05 \\
\text { nificant } \\
\text { difference }\end{array}\right\} p=0.01$ & $\begin{array}{l}0.5 \\
0.6\end{array}$ & $\begin{array}{l}3.5 \\
4.6\end{array}$ & $\begin{array}{c}4.9 \\
\text { n.s. }+\end{array}$ & \\
\hline Mean of cultivars & 3.8 & 26.9 & 30.0 & 7.1 \\
\hline
\end{tabular}

- Condensate = TPM - nicotine $-\mathrm{H}_{2} \mathrm{O}$.

* The clgarettes were $85 \mathrm{~mm}$ long and smoked to a butt length of $23 \mathrm{~mm}$; therefore, the condensate $/ \mathrm{g}$ of tobacco smoked was based on the weight of the $62 \mathrm{~mm}$ smoked.

+ n.s. $=$ not significant.

densate / $\mathrm{g}$ of tobacco smoked ranged from $26.6 \mathrm{mg} / \mathrm{g}$ (Hicks-Mammoth) to 35.2 (Coker 319). When the condensate / $g$ of tobacco smoked was calculated, the range was not as great. Condensate / $\mathrm{g}$ of tobacco smoked is a better measurement of the genotype potential for condensate delivery than condensate/cigarette. The condensate : nicotine ratio ranged from 6.3 for TI 1480 to 44.2 for LAFC 53. The test indicated that Maryland 609 condensate delivery was low. Also, Wernsman et al. (13) concluded the PMI was lower for Maryland cultivars.

\section{Effect of Curing on Condensate Delivery Levels} of Maryland and Flue-cured Tobacco

Three cultivars were compared: Maryland 609, NC 2326, and Coker 319. Each cultivar was subjected to both air and flue-curing. The tobacco was grown at Whiteville,
Table 2. Values for several measurements of tobacco smoke with varying nicotine and condensate levels (2-year mean).

\begin{tabular}{|c|c|c|c|c|}
\hline $\begin{array}{c}\text { Tobacco line } \\
\text { or } \\
\text { cultivar }\end{array}$ & $\begin{array}{c}\text { Nicotine / } \\
\text { cigarette } \\
(\mathrm{mg})\end{array}$ & $\begin{array}{l}\text { Conden- } \\
\text { sate* / } \\
\text { cigarette } \\
(\mathrm{mg})\end{array}$ & $\begin{array}{l}\text { Conden- } \\
\text { sate / g of } \\
\text { tobacco } \\
\text { smoked"* } \\
(\mathrm{mg})\end{array}$ & $\begin{array}{c}\text { Conden- } \\
\text { sate : nic- } \\
\text { otine }\end{array}$ \\
\hline TI 383 & 2.3 & 27.1 & 30.9 & 11.8 \\
\hline TI 1335 & 4.7 & 35.8 & 33.2 & 7.6 \\
\hline TI 1480 & 3.6 & 22.7 & 28.4 & 6.3 \\
\hline TI 1502 & 3.9 & 31.4 & 30.1 & 8.1 \\
\hline TI 1503 & 2.9 & 25.9 & 33.1 & 8.9 \\
\hline Amarello 5 & 2.6 & 23.9 & 29.8 & 9.2 \\
\hline Gold Leaf & 3.0 & 27.1 & 31.3 & 9.1 \\
\hline 135 & 2.3 & 24.5 & 28.7 & 10.7 \\
\hline SC 71 & 2.1 & 29.1 & 33.2 & 13.9 \\
\hline PD 682 & 2.8 & 28.1 & 30.6 & 10.2 \\
\hline White-Stem-Orino & 2.7 & 28.9 & 32.4 & 10.7 \\
\hline Greeneville 48 & 1.7 & 19.9 & 27.8 & 11.7 \\
\hline Hicks-Mammoth & 1.9 & 19.7 & 26.6 & 10.4 \\
\hline Coker 187 (Mamm & oth) 1.6 & 25.4 & 32.2 & 15.9 \\
\hline SC 58 & 4.0 & 27.7 & 30.8 & 6.9 \\
\hline Coker 139 & 2.1 & 27.6 & 33.5 & 13.1 \\
\hline LAFC 53 & 0.6 & 25.3 & 29.0 & 44.2 \\
\hline Burley 21 & 3.1 & 23.7 & 31.6 & 7.6 \\
\hline NC 95 & 3.5 & 26.7 & 30.1 & 7.6 \\
\hline Md. 609 & 2.4 & 21.6 & 27.3 & 9.0 \\
\hline Coker 319 & 3.2 & 30.3 & 35.2 & 9.5 \\
\hline Speight G-28 & 2.8 & 25.0 & 28.6 & 8.9 \\
\hline \multirow{2}{*}{$\left.\begin{array}{l}\text { Least sig- } \\
\text { nificant } \\
\text { difference }\end{array}\right\} p=0.0$} & 1.1 & 4.8 & 4.2 & \\
\hline & 1.5 & 6.5 & 5.7 & \\
\hline
\end{tabular}

* Condensate $=$ TPM - nicotine $-\mathrm{H}_{2} \mathrm{O}$.

** The cigarettes were $85 \mathrm{~mm}$ long and smoked to a butt length of $23 \mathrm{~mm}$; therefore, the condensate $/ \mathrm{g}$ of tobacco smoked was based on the weight of the $62 \mathrm{~mm}$ smoked.

N. C., by using the same production practices as for flue-cured, including transplanting, cultivation, fertilization, and sucker control treatment with maleic hydrazide (1). Cigarettes were made from the cured leaf and smoked by the method previously described in this paper.

Condensate/cigarette was lower for air-cured than for fluecured tobacco. Cigarettes from Maryland 609 delivered less condensate than those from the flue-cured cultivars when they were either air or flue-cured (Table 3). The nicotine in the smoke was related to the total alkaloids in the cured leaf; however, the smoke from Maryland 609 had less nicotine/cigarette than that from either of the flue-cured cultivars. When condensate / $g$ of tobacco smoked was compared there was no difference between cultivars when flue-cured. Also, there was no difference in condensate / $g$ of tobacco smoked for flue-cured culti- 
Table 3. Smoke analysls of Md. 609, NC 2326 and Coker 319 tobacco cultivars when flue and alr-cured (1).

\begin{tabular}{|c|c|c|c|c|c|c|}
\hline $\begin{array}{l}\text { Curing } \\
\text { method }\end{array}$ & Cultivars & $\begin{array}{c}\text { Total alkaloids } \\
\text { in the leaf } \\
(\%)\end{array}$ & $\begin{array}{l}\text { Nicotine / } \\
\text { cigarette } \\
\text { (mg) }\end{array}$ & $\begin{array}{c}\text { Condensate } \theta^{*} / \\
\text { cigarette } \\
\text { (mg) }\end{array}$ & $\begin{array}{c}\text { Condensate / g } \\
\text { of tobacco } \\
\text { smoked ** } \\
\text { (mg) }\end{array}$ & $\begin{array}{l}\text { Condensate : } \\
\text { nicotine }\end{array}$ \\
\hline \multirow[t]{3}{*}{ Flue-cured } & Md. 609 & 2.4 & 2.3 & 26.7 & 30.4 & 11.6 \\
\hline & NC 2326 & 2.5 & 3.0 & 32.1 & 29.5 & 10.7 \\
\hline & Coker 319 & 2.3 & 2.8 & 31.0 & 30.7 & 11.1 \\
\hline \multirow[t]{3}{*}{ Air-cured } & Md. 609 & 0.8 & 0.7 & 18.6 & 23.3 & 26.6 \\
\hline & NC 2326 & 1.1 & 1.0 & 23.9 & 29.2 & 23.9 \\
\hline & Coker 319 & 1.0 & 0.9 & 23.3 & 30.1 & 25.9 \\
\hline
\end{tabular}

* Condensate $=$ TPM - nicotine $-\mathrm{H}_{2} \mathrm{O}$.

** The cigarettes were $85 \mathrm{~mm}$ long and smoked to a butt length of $23 \mathrm{~mm}$; therefore, the condensate/g of tobacco smoked was based on the weight of the $62 \mathrm{~mm}$ smoked.

vars, whether air or flue-cured. There was lower condensate / $\mathrm{g}$ of tobacco smoked when Maryland 609 was air-cured.

\section{Effect of Burley and Flue-cured Genotypes on Condensate Delivery}

Five flue-cured and five Burley cultivars were evaluated at Reidsville, N.C. (5). All lines were grown in singlerow plots consisting of 20 competitive plants under fluecured culture. All plots were hand-primed and flue- cured. A representative sample of leaves was collected from each plot, midribs were removed and lamina was made into cigarettes.

Statistically significant differences in smoke components were found for seven of the ten traits, but all Burley cultivars were not significantly different from all fluecured cultivars for any trait (Table 4). Burley cultivars were generally higher in condensate/g of tobacco smoked. There were significant differences among Burley cultivars in condensate/ $g$ of tobacco smoked and in condensate : nicotine ratio.

Table 4. Meane tor smoke components in Burley and flue-cured tobacco cultivars at Reidsville, North Carolina (4).

\begin{tabular}{|c|c|c|c|c|}
\hline Cultivar & $\begin{array}{c}\text { Nicotine / cigarette } \\
\text { (mg) }\end{array}$ & $\begin{array}{c}\text { Condensate } \\
\text { cigarette } \\
\text { (mg) }\end{array}$ & $\begin{array}{c}\text { Condensate / g } \\
\text { of tobacco smoked ** } \\
\text { (mg) }\end{array}$ & Condensate : nicotine \\
\hline \multicolumn{5}{|l|}{ Flue-cured } \\
\hline Virginia Gold & $3.7 \mathrm{~cd}^{+}$ & 29.5 & $26.8 \mathrm{abc}$ & 8.0abcd \\
\hline Bottom Special & $2.5 a$ & 25.3 & $23.9 a b$ & $10.1 b$ \\
\hline Hicks Broadleaf & $3.9 \mathrm{~cd}$ & 30.4 & $25.9 a b c$ & $7.8 \mathrm{abcd}$ \\
\hline Coker 139 & $2.8 \mathrm{ab}$ & 26.3 & $23.7 a b$ & $9.4 \mathrm{~cd}$ \\
\hline Coker 140 & $3.0 \mathrm{abc}$ & 27.2 & $24.8 a b c$ & $9.1 \mathrm{~cd}$ \\
\hline Mean for flue-cured & 3.2 & 27.8 & 25.0 & 8.7 \\
\hline \multicolumn{5}{|l|}{ Burley } \\
\hline Virginia B 29 & $4.2 \mathrm{~d}$ & 28.8 & $32.6 \mathrm{c}$ & $6.9 \mathrm{ab}$ \\
\hline Burley 49 & $3.7 \mathrm{~cd}$ & 21.0 & $22.5 \mathrm{a}$ & $5.7 \mathrm{a}$ \\
\hline Ky. 14 & $3.6 \mathrm{bcd}$ & 26.8 & $30.6 \mathrm{bc}$ & $7.4 \mathrm{bcd}$ \\
\hline Ky. 12 & $3.5 \mathrm{bcd}$ & 25.4 & $29.8 a b c$ & $7.3 \mathrm{abc}$ \\
\hline Ky. Experimental 42 & $4.1 d$ & 24.4 & $31.2 \mathrm{bc}$ & $6.1 \mathrm{ab}$ \\
\hline Mean for Burley & 3.8 & 25.5 & 29.4 & 6.7 \\
\hline
\end{tabular}

* Condensate $=$ TPM - nicotine $-\mathrm{H}_{2} \mathrm{O}$.

*" The cigarettes were $85 \mathrm{~mm}$ long and smoked to a butt length of $23 \mathrm{~mm}$; therefore, the condensate/g of tobacco smoked was based on the weight of the $62 \mathrm{~mm}$ smoked.

+ Means followed by different letters are significantly different at $p=0.05$ by Duncan's new multiple range test. 
Condensate / $\mathrm{g}$ of tobacco smoked was a better parameter than condensate/cigaretre for studying genetic variability for condensate delivery, because of variations in physical traits of cigarettes. All of the flue-cured cultivars were lower than Burley cultivars in delivery of condensate / $\mathrm{g}$ of tobacco smoked. Burley 49 was an exception with condensate delivery equal to that of fluecured cultivars.

\section{Comparison of Condensate Delivery to Genetically Altered Nicotine Levels.}

In 1967, a project was initiated at the Oxford Tobacco Research Laboratory to transfer the genetic trait for low nicotine into several commercial cultivars of flue-cured tobacco and to determine the influence of this trait on other characteristics (2). The low nicotine character was transferred into 10 flue-cured cultivars by the backcross method. The cultivars used as recurring parents were: Hidss, Va. 115, Coker 258, McNair 12, NC 2326, Coker 298, SC 71, SC 58, NC 95 and Coker 139. Five lownicotine lines in each of these families were produced and tested at three locations in North Carolina in 1973 and 1974. In general, the low-alkaloid lines delivered slightly lower condensate than did their parents (Table 5). On an average, this was $4 \mathrm{mg}$ of condensate/cigarette; however, when the condensate/g of tobacco smoked was calculated, the differences were not as large. Therefore, condensate delivery did not decrease appreciably when nicotine levels were decreased but the condensate : nicotine ratio increased considerably. The use of low-nicotine lines to reduce condensate delivery may not be desirable.

\section{Particulate Matter Index of}

\section{- Tobacco Introductions and Cultivars}

One hundred and eighty lines and cultivars were grown at Oxford, North Carolina, in 1977 and 1978. The lines represent a wide range of material; however, most were selected from the Tobacco Introduction (TI) group maintained by the U.S. Department of Agriculture. Extreme variations in growth characteristics were sought. The material was replicated twice in both years and PMI and percent total alkaloids (TA) were determined on cured leaf.

There was considerable variation for PMI between years. The average index ranged from 202 for PI 418595 to 285 for TI 426 (Table 6). There appeared to be an association between percent total alkaloids in the leaf and the PMI. For example, Nicotiana rustica had the highest level of total alkaloids $(8.78 \%$ ) with a PMI of 279 , whereas PI 418597 had an alkaloid content of $1.97 \%$ and a PMI of 230. In a comparison of cultivars and classes of tobacco for their PMI, Ky. 16 (Burley) had 252, Conn. Shade (cigar wrapper) had 270, Va. 310 (dark fire-cured) had 273, and Turkish cultivars were all high. The flue-cured lines were lower; NC 2326 and NC 95 had 235 and 238, respectively; Coker 139 was lowest of the flue-cured with 226 while SC 58 was somewhat higher with 240. Maryland 609 had 234.
Table 5. Comparison of the low-alkalold lines with their recurrent parent as regards their average smoke composition (2).

\begin{tabular}{|c|c|c|c|c|}
\hline $\begin{array}{l}\text { Recurrent } \\
\text { parent } \\
\text { and line }\end{array}$ & $\begin{array}{c}\text { Nicotine / } \\
\text { cigarette } \\
(\mathrm{mg})\end{array}$ & $\begin{array}{c}\text { Conden- } \\
\text { sate* / } \\
\text { cigarette } \\
\text { (mg) }\end{array}$ & $\begin{array}{c}\text { Conden- } \\
\text { sate / g of } \\
\text { tobacco } \\
\text { smoked ** } \\
\text { (mg) }\end{array}$ & $\begin{array}{c}\text { Conden- } \\
\text { sate : nic- } \\
\text { otine }\end{array}$ \\
\hline Hicks & 3.5 & 42.4 & 38.7 & 12.1 \\
\hline Low-alkaloid lines ${ }^{+}$ & 0.9 & 37.8 & 42.4 & 42.0 \\
\hline Va. 115 & 3.5 & 41.0 & 43.2 & 11.7 \\
\hline Low-alkaloid lines & 0.7 & 35.5 & 42.3 & 50.7 \\
\hline Coker 258 & 3.3 & 44.4 & 50.7 & 13.5 \\
\hline Low-alkaloid lines ${ }^{+}$ & 0.9 & 39.3 & 47.2 & 43.7 \\
\hline McNair 12 & 3.2 & 38.5 & 40.6 & 12.0 \\
\hline Low-alkaloid lines ${ }^{+}$ & 0.7 & 36.4 & 40.5 & 52.0 \\
\hline NC 2326 & 3.2 & 43.2 & 47.3 & 13.5 \\
\hline Low-alkaloid lines ${ }^{+}$ & 0.5 & 37.7 & 43.0 & 75.4 \\
\hline Coker 298 & 3.6 & 38.6 & 42.3 & 10.7 \\
\hline Low-alkaloid lines ${ }^{+}$ & 0.8 & 36.8 & 41.3 & 46.0 \\
\hline SC 71 & 3.3 & 40.2 & 45.9 & 12.2 \\
\hline Low-alkaloid lines ${ }^{+}$ & 0.6 & 32.5 & 42.4 & 54.2 \\
\hline SC 58 & 4.3 & 41.0 & 46.8 & 9.5 \\
\hline Low-alkaloid lines ${ }^{+}$ & 0.8 & 37.8 & 43.5 & 47.3 \\
\hline NC 95 & 3.3 & 38.6 & 39.2 & 11.7 \\
\hline Low-alkaloid lines ${ }^{+}$ & 0.8 & 37.5 & 43.9 & 46.9 \\
\hline Coker 319 & 2.8 & 39.7 & 43.5 & 14.2 \\
\hline Low-alkaloid lines+ & 0.5 & 36.2 & 40.6 & 72.4 \\
\hline Mean parent & 3.4 & 40.8 & 43.8 & 12.0 \\
\hline $\begin{array}{l}\text { Mean } \\
\text { low-alkaloid lines }\end{array}$ & 0.7 & 36.8 & 42.7 & 52.6 \\
\hline
\end{tabular}

* Condensate = TPM - nicotine $-\mathrm{H}_{2} \mathrm{O}$.

** The cigarettes were $85 \mathrm{~mm}$ long and smoked to a butt length of $23 \mathrm{~mm}$; therefore, the condensate $/ \mathrm{g}$ of tobacco smoked was based on the weight of the $62 \mathrm{~mm}$ smoked.

+ Values for low-alkaloid lines are means of five lines in each family.

\section{Lowering the Condensate: Nicotine Ratio}

Data from previous tests suggested that the best way to lower the condensate : nicotine ratio is by increasing the nicotine level and, at the same time, maintaining or lowering condensate levels. High nicotine lines were selected from the germplasm bank maintained by the Oxford Tobacco Research Laboratory, to test the condensate : nicotine ratio. In 1979, these lines and several others were planted. In that test, yield and other agronomic characteristics were not considered. The ratio of condensate : nicotine ranged from 5.3 (TI 717) to 75.0 for one of the low-nicotine lines (Table 7). Nicotiana rustica which had a ratio of 7.1 was also included in the test. 
Table 6. Particulate matter Index (PMI) on certain lines of tobacco (Oxford, North Carolina).

\begin{tabular}{|c|c|c|c|c|c|c|}
\hline Line & & $\begin{array}{c}\text { Total alkaloids } \\
(\% / 0)\end{array}$ & $\begin{array}{c}\text { PMI } \\
(\mathrm{mg} / \mathrm{g})\end{array}$ & $\operatorname{Lin} \theta$ & $\begin{array}{c}\text { Total alkaloids } \\
(\% / 0)\end{array}$ & $\begin{array}{l}\text { PMI } \\
(\mathrm{mg} / \mathrm{g})\end{array}$ \\
\hline TI 7 & & 5.5 & 255 & TI 719 & 6.2 & 254 \\
\hline TI 79 & & 6.0 & 273 & T! 720 & 6.2 & 255 \\
\hline TI 85 & . & 6.6 & 260 & TI 729 & 6.3 & 270 \\
\hline$T 187$ & & 5.5 & 258 & TI 731 & 7.4 & 279 \\
\hline TI 88 & & 6.4 & 258 & TI 732 & 5.3 & 267 \\
\hline TI 92 & & 5.9 & 262 & TI 748 & 6.3 & 259 \\
\hline TI 93 & & 5.1 & 264 & TI 752 & 6.3 & 254 \\
\hline TI 94 & & 5.5 & 250 & TI 764 & 5.5 & 252 \\
\hline TI 97 & & 4.1 & 244 & TI 767 & 4.2 & 247 \\
\hline TI 125 & & 6.3 & 275 & TI 780 & 6.0 & 254 \\
\hline TI 135 & & 6.0 & 255 & T) 782 & 6.0 & 253 \\
\hline TI 154 & & 6.4 & 252 & TI 799 & 5.7 & 267 \\
\hline TI 164 & & 6.0 & 261 & TI 804 & 6.0 & 272 \\
\hline TI 173 & . & 5.4 & 255 & TI 814 & 7.3 & 273 \\
\hline TI 177 & & 6.1 & 265 & TI 820 & 6.2 & 248 \\
\hline TI 180 & & 6.1 & 267 & TI 821 & 6.8 & 270 \\
\hline TI 184 & . & 5.7 & 261 & TI 822 & 5.7 & 262 \\
\hline TI 186 & & 4.5 & 235 & TI 824 & 6.3 & 262 \\
\hline TI 187 & & 4.9 & 244 & TI 874 & 5.7 & 274 \\
\hline TI 205 & & 7.1 & 248 & TI 875 & 6.5 & 261 \\
\hline TI 233 & & $7.5^{\circ}$ & 271 & TI 916 & 7.1 & 273 \\
\hline TI 285 & & 5.4 & 268 & TI 918 & 7.7 & 283 \\
\hline TI 307 & & 6.4 & 244 & TI 935 & 5.1 & 256 \\
\hline TI 310 & & 6.4 & 274 & TI 937 & 7.8 & 283 \\
\hline T1 328 & & 7.0 & 266 & TI 942 & 5.7 & 258 \\
\hline TI 340 & & 6.2 & 246 & TI 960 & 4.4 & 255 \\
\hline T1 366 & & 6.5 & 267 & TI 968 & 5.3 & 270 \\
\hline TI 372 & & 5.9 & 256 & TI 983 & 6.1 & 249 \\
\hline TI 375 & & 6.9 & 255 & TI 990 & 6.5 & 275 \\
\hline TI 380 & & 5.9 & 257 & TI 1073 & 5.0 & 253 \\
\hline TI 401 & & 5.8 & 256 & TI 1097 & 5.3 & 267 \\
\hline TI 421 & & 5.4 & 266 & TI 1110 & 5.5 & 248 \\
\hline T1 422 & & 6.3 & 263 & TI 1123 & 7.9 & 253 \\
\hline TI 423 & & 6.3 & 272 & TI 1125 & 6.5 & 257 \\
\hline TI 425 & & 7.6 & 278 & TI 1229 & 7.0 & 256 \\
\hline TI 426 & & 7.6 & 285 & TI 1239 & 5.6 & 253 \\
\hline TI 432 & & 5.8 & 271 & TI 1241 & 6.2 & 258 \\
\hline TI 433 & & 6.8 & 279 & TI 1242 & 6.3 & 258 \\
\hline TI 451 & & 5.3 & 246 & TI 1253 & 7.1 & 263 \\
\hline TI 453 & & 6.2 & 273 & TI 1269 & 6.2 & 266 \\
\hline TI 455 & & 6.4 & 282 & TI 1271 & 6.2 & 269 \\
\hline TI 463 & & 4.2 & 251 & TI 1286 & 5.8 & 263 \\
\hline TI 464 & & 7.4 & 273 & TI 1299 & 7.4 & 268 \\
\hline TI 483 & & 6.3 & 266 & TI 1301 & 7.8 & 276 \\
\hline TI 487 & & 5.3 & 258 & TI 1302 & 8.0 & 283 \\
\hline TI 489 & & 7.1 & 284 & TI 1303 & 5.2 & 263 \\
\hline TI 490 & & 4.4 & 252 & TI 1308 & 7.4 & 272 \\
\hline TI 492 & & 5.0 & 253 & TI 1309 & 7.1 & 258 \\
\hline TI 502 & & 5.0 & 245 & TI 1311 & 7.5 & 265 \\
\hline TI 500 & & 6.1 & 268 & TI 1313 & 7.1 & 265 \\
\hline TI 536 & & 6.3 & 272 & TI 1321 & 5.4 & 234 \\
\hline TI 538 & & 4.9 & 259 & TI 1335 & 6.3 & 266 \\
\hline TI 540 & & 6.6 & 279 & TI 1347 & 5.2 & 240 \\
\hline TI 553 & & 5.9 & 268 & TI 1381 & 6.1 & 253 \\
\hline TI 556 & & 6.1 & 281 & TI 1420 & 6.7 & 266 \\
\hline TI 589 & & 6.2 & 283 & TI 1453 & 6.4 & 259 \\
\hline TI 592 & & 5.9 & 271 & T1 1495 & 6.7 & 268 \\
\hline TI 604 & & 6.2 & 268 & TI 1496 & 5.9 & 251 \\
\hline TI 683 & & 7.5 & 270 & Coker 213 & 4.5 & 248 \\
\hline TI 717 & & 6.7 & 262 & Oxford $1-181$ & 5.1 & 250 \\
\hline
\end{tabular}




\begin{tabular}{|c|c|c|c|c|c|}
\hline Line & $\begin{array}{c}\text { Total alkaloids } \\
(\% / 0)\end{array}$ & $\begin{array}{c}\text { PMI } \\
(\mathrm{mg} / \mathrm{g})\end{array}$ & Line & $\begin{array}{c}\text { Total alkaloids } \\
(\% / 0)\end{array}$ & $\begin{array}{c}\text { PMI } \\
(\mathrm{mg} / \mathrm{g})\end{array}$ \\
\hline Oxford 2 & 4.8 & 256 & Va. 310 & 5.6 & 273 \\
\hline PD 114 & 5.4 & 261 & Kavalla & 4.8 & 263 \\
\hline PD 468 & 5.1 & 257 & Smyrna & 4.8 & 266 \\
\hline sc 58 & 4.8 & 240 & Xanthi-Yaka & 5.8 & 270 \\
\hline Smith $\mathrm{TI} 79 \mathrm{~A}$ & 6.3 & 271 & Samsun & 7.1 & 282 \\
\hline Smith $79 x$ & 7.1 & 268 & Xanthi (Smith) & 7.0 & 264 \\
\hline Vesta 64 & 4.1 & 241 & Xanthi (Mitchell) & 7.0 & 274 \\
\hline White Mammoth & 3.6 & 241 & Xanthi-N & 6.2 & 268 \\
\hline Gr 44 & 4.0 & 247 & C-20 & 3.0 & 246 \\
\hline Kelly Burley & 4.7 & 257 & N. Rustica Brasilia & 8.8 & 279 \\
\hline Ky. 16 & 4.9 & 252 & $\mathrm{C}-21$ & 2.3 & 229 \\
\hline DSTC & 5.0 & 254 & $\mathrm{C}-22$ & 2.0 & 228 \\
\hline Bell $B$ & 4.8 & 253 & PI 418592 & 2.8 & 242 \\
\hline Bell C & 5.3 & 260 & PI 418593 & 2.0 & 217 \\
\hline CG 1 & 6.2 & 255 & PI 418594 & 3.8 & 235 \\
\hline CG 2 & 5.1 & 247 & PI 418595 & 2.2 & 202 \\
\hline CW 3 (FL) & 5.7 & 268 & PI 418596 & 3.1 & 227 \\
\hline CW 3 (WSL) & 5.3 & 261 & PI 418597 & 1.9 & 230 \\
\hline Conn. Bdl. & 5.6 & 256 & PI 420731 & 2.5 & 245 \\
\hline Conn. Shade & 6.6 & 270 & 13 & 3.1 & 252. \\
\hline Conn. 49 & 4.5 & 253 & 114 & 6.0 & 270 \\
\hline Fla. 301 & 5.6 & 251 & 162 & 5.3 & 250 \\
\hline Conn. 911 & 6.1 & 251 & 166 & 3.8 & 263 \\
\hline$M-2$ & 5.0 & 241 & NC 2326 & 3.4 & 235 \\
\hline $56-96$ & 5.4 & 250 & NC 95 & 4.2 & 238 \\
\hline CW 396 & 5.4 & 254 & PY 10 & 3.4 & 241 \\
\hline CW 658 & 6.0 & 257 & Md. 609 & 4.0 & 234 \\
\hline Little Hill & 4.8 & 255 & Coker 139 & 3.1 & 226 \\
\hline Hav. K2-2X & 6.6 & 250 & TI 1112 & 4.1 & 244 \\
\hline Hav. 263 & 6.1 & 266 & & & \\
\hline
\end{tabular}

SC 58, a flue-cured cultivar with a high level of nicotine, had a ratio of 8.9 .

The condensate and nicotine deliveries from $N$. rustica were generally higher than those from $N$. tabacum and the condensate : nicotine ratio was generally lower for the smoke from $N$. rustica than that for the smoke from most flue-cured tobacco cultivars. The gene(s) responsible for production of nicotine in $N$. rustica were transferred into $N$. tabacum. Unfortunately, the nicotine levels in the derived lines were not much different from those already in N. tabacum. A series of crosses was made between the derived lines and cultivars of $N$. tabacum. In most instances, the levels of nicotine were not higher than the $N$. tabacum parent. From one series of crosses involving $N$. rustica-derived lines and SC 58, however, high levels of nicotine were obtained. The levels in general were about $1.00 \%$ total alkaloids higher than SC 58.

Several of the derived lines were grown in a replicated test in 1979 at two locations in North Carolina. All of the lines had higher nicotine levels than SC 58 but lower than $N$. rustica (Table 8). The condensate delivery/g of tobacco smoked was lower for the lines when compared with SC 58 and all of them gave a condensate : nicotine ratio lower than SC 58. The indications are that progress is being made in lowering the condensate : nicotine ratio in this material.

One hindrance to lowering condensate delivery in tobacco by plant breeding is the procedure for assaying large numbers of samples. The PMI method tends to alleviate this, but a better, faster method is needed. A multiple regression technique involving selected chemical analyses of cured leaf may offer an additional method. Williamson and Chaplin (14) reported a method for predicting condensate levels by multiple regression procedures by using data from various chemical determinations on the cured leaf. Chemicals determined were: petroleum ether extract, alcohol-chloroform extract, wax, holocellulose, total alkaloids, total nitrogen, alpha amino nitrogen, polyphenols, ash, reducing sugars, and starch. A high level of precision in predicting the condensate deliveries was obtained by using data from seven of the chemical constituents. Data from as few as four chemical constituents of the leaf were useful in developing a prediction equation for the estimation of condensate in tobacco smoke. 
Table 7. Smoke constituents of certain tobacco lines (Oxford, North Carolina).

\begin{tabular}{|c|c|c|c|c|}
\hline $\begin{array}{c}\text { Line } \\
\text { or } \\
\text { cultivar }\end{array}$ & $\begin{array}{c}\text { Nicotine / } \\
\text { clgarette } \\
\text { (mg) }\end{array}$ & $\begin{array}{c}\text { Conden- } \\
\text { sate* / } \\
\text { cigarette } \\
(\mathrm{mg})\end{array}$ & $\begin{array}{c}\text { Conden- } \\
\text { sate / g of } \\
\text { tobacco } \\
\text { smoked ** } \\
\text { (mg) }\end{array}$ & $\begin{array}{l}\text { Conden- } \\
\text { sate: nic- } \\
\text { otlne }\end{array}$ \\
\hline TI 186 & 4.3 & 39.2 & 49.9 & 9.1 \\
\hline TI 205 & 5.2 & 64.7 & 55.5 & 12.4 \\
\hline TI 233 & 8.1 & 45.6 & 45.9 & 5.6 \\
\hline T1 328 & 5.7 & 44.0 & 41.3 & 7.7 \\
\hline TI 340 & 5.4 & 44.0 & 40.8 & 8.1 \\
\hline TI 375 & 7.2 & 44.7 & 45.0 & 6.2 \\
\hline TI 425 & 5.4 & 44.2 & 48.0 & 8.2 \\
\hline TI 451 & 3.6 & 34.3 & 36.7 & 9.5 \\
\hline TI 464 & 6.4 & 50.5 & 53.2 & 7.9 \\
\hline TI 502 & 5.5 & 44.6 & 55.5 & 8.1 \\
\hline TI 717 & 7.6 & 40.4 & 42.6 & 5.3 \\
\hline TI 752 & 5.9 & 47.7 & 53.6 & 8.1 \\
\hline TI 814 & 6.5 & 45.9 & 48.3 & 7.1 \\
\hline TI 1241 & 6.8 & 46.2 & 53.7 & 6.8 \\
\hline TI 1299 & 6.5 & 46.8 & 50.9 & 7.2 \\
\hline TI 1308 & 6.1 & 52.4 & 47.9 & 8.6 \\
\hline TI 1309 & 5.9 & 46.8 & 44.2 & 7.9 \\
\hline T1 1311 & 6.6 & 46.6 & 45.6 & 7.1 \\
\hline TI 1313 & 6.9 & 34.7 & 41.7 & 5.0 \\
\hline TI 1420 & 5.8 & 36.1 & 42.6 & 6.2 \\
\hline Smith $79 x$ & 6.2 & 51.2 & 50.9 & 8.3 \\
\hline PI 418593 & 2.9 & 39.6 & 37.1 & 13.7 \\
\hline PI 418594 & 5.7 & 36.2 & 43.5 & 6.4 \\
\hline PI 418596 & 3.9 & 38.2 & 36.9 & 9.8 \\
\hline PI 420731 & 5.0 & 44.1 & 42.5 & 8.8 \\
\hline NC 2326 & 5.3 & 41.3 & 41.6 & 7.8 \\
\hline NC 95 & 4.8 & 35.6 & 39.4 & 7.4 \\
\hline PY 10 & 5.5 & 38.9 & 41.6 & 7.1 \\
\hline Md. 609 & 4.0 & 28.3 & 38.0 & 7.1 \\
\hline Coker 139 & 3.2 & 37.6 & 39.1 & 11.8 \\
\hline PI 418595 & 3.6 & 36.1 & 38.6 & 10.0 \\
\hline SC 58 & 5.0 & 44.3 & 44.6 & 8.9 \\
\hline Speight G-28 & 3.8 & 33.4 & 38.8 & 8.8 \\
\hline Pale Yellow Mammotl & th 3.8 & 37.2 & 43.2 & 9.8 \\
\hline Coker 187 (Mammoth) & th) 3.2 & 41.6 & 50.9 & 13.0 \\
\hline LAFC 53 & 0.8 & 28.8 & 28.8 & 36.0 \\
\hline LA 11 & 0.7 & 32.1 & 32.1 & 45.9 \\
\hline LA 21 & 0.7 & 27.5 & 31.4 & 39.3 \\
\hline LA 38 & 0.6 & 29.3 & 33.5 & 48.8 \\
\hline LA 39 & 0.4 & 29.8 & 36.4 & 75.0 \\
\hline LA 46 & 1.0 & 31.6 & 29.5 & 31.6 \\
\hline LA 56 & 0.6 & 27.9 & 32.7 & 47.0 \\
\hline N. Rustica Brasilia & 6.7 & 47.8 & 49.6 & 7.1 \\
\hline
\end{tabular}

- Condensate $=$ TPM - nicotine $-\mathrm{H}_{2} \mathrm{O}$.

** The clgarettes were $85 \mathrm{~mm}$ long and smoked to a butt length of $23 \mathrm{~mm}$; therefore, the condensate/g of tobacco smoked was based on the weight of the $62 \mathrm{~mm}$ smoked.

\section{CONCLUSIONS}

1. Condensate deliveries among lines of tobacco varied with the environment, cultural practices, and the weather conditions under which the tobacco was produced.
Table 8. Comparison of condensate and nicotine levels among standard tobacco cultivars and $\mathrm{N}$. rustica-derived Ilnes.

\begin{tabular}{l|c|c|c|c}
\hline $\begin{array}{c}\text { Cultivar } \\
\text { or } \\
\text { line }\end{array}$ & $\begin{array}{c}\text { Nicotine / } \\
\text { cigarette } \\
(\mathrm{mg})\end{array}$ & $\begin{array}{c}\text { Conden- } \\
\text { sate* / } \\
\text { cigarette } \\
(\mathrm{mg})\end{array}$ & $\begin{array}{c}\text { Conden- } \\
\text { sate/g af } \\
\text { tobacco } \\
\text { smoked ** } \\
\text { (mg) }\end{array}$ & $\begin{array}{c}\text { Conden- } \\
\text { sate : nic- } \\
\text { otine }\end{array}$ \\
\hline 129 & 5.6 & 36.2 & 35.9 & 6.5 \\
131 & 5.1 & 26.4 & 30.6 & 5.2 \\
132 & 5.0 & 27.8 & 34.0 & 5.6 \\
133 & 5.2 & 29.8 & 35.2 & 5.7 \\
134 & 5.0 & 26.7 & 31.0 & 5.3 \\
135 & 5.4 & 30.2 & 36.9 & 5.6 \\
SC 58 & 4.7 & 32.7 & 37.6 & 7.0 \\
NC 95 & 4.1 & 34.1 & 33.6 & 8.3 \\
N. rustica Brasilia & 6.7 & 43.8 & 45.4 & 6.5 \\
\hline
\end{tabular}

* Condensate $=$ TPM - nicoline $-\mathrm{H}_{2} \mathrm{O}$.

** The cigarettes were $85 \mathrm{~mm}$ long and smoked to a butt length of $23 \mathrm{~mm}$; therefore, the condensate/g of tobacco smoked was based on the welght of the $62 \mathrm{~mm}$ smoked.

2. Condensate / $g$ of tobacco smoked is a better index than condensate/cigarette for evaluation of condensate delivery of breeding lines.

3. The range of condensate deliveries and the condensate : nicotine ratios for present flue-cured cultivars are small.

4. When classes of tobacco were compared for condensate deliveries, Burley was high and Maryland low.

5. Flue-cured generally delivered less condensate than Burley.

6. Low-nicotine tobaccos do not have the potential for lowering condensate delivery, because of their high condensate : nicotine ratios.

7. The particulate matter index (PMI) may be used to screen large numbers of samples; however, a smoke test is required prior to making a final judgment as to condensate deliveries.

8. The PMI appeared to correlate better with condensate/g of tobacco smoked than with condensate/cigarette.

9. To alter the condensate : nicotine ratio the high-nicotine lines appeared most promising.

10. Condensate deliveries from tobacco are controlled by multiple genetic factors. Breeding procedures which accumulate large numbers of genes should be the best method to use. This does not preclude the use of other methods such as the pedigree, dihaploid and interspecific hybridization.

11. For the breeder to develop lines that deliver low condensate and have good smoking flavor, it will be necessary, simultaneously, to select for certain flavor 
compounds. More research is needed in this area so that breeders will be able to select for certain flavor-related constituents.

12. Condensate and nicotine deliveries appear to be associated; therefore, selections for both nicotine and condensate are necessary in order to modify the condensate : nicotine ratio.

13. More evaluation, such as their smokeability, is needed on lines of tobacco with high nicotine levels.

\section{SUMMARY}

Condensate deliveries from cigarettes can be reduced by manufacturers in various ways. Lines or cultivars of tobacco can also be developed whose cured leaf, upon pyrolysis, delivers less condensate in the smoke. Since there appears to be an association between condensate and nicotine in smoke, the condensate : nicotine ratio is important to the development of lines of tobacco that deliver low condensate levels. Experiments were conducted to evaluate the potential for genetically controlling condensate delivery in cigarette smoke and data are presented. In general, when comparing the condensate delivery potential for different classes of tobacco, Burley delivered higher condensate values followed by dark fire-cured, dark air-cured, flue-cured and Maryland cultivars. In selecting genotypes for lowering condensate deliveries, the condensate/ $\mathrm{g}$ of tobacco smoked is a better index than condensate/cigarette. In evaluating low-alkaloid tobaccos, the condensate delivery did not decrease appreciably as the total alkaloids were decreased. On an average, the decrease was about $4 \mathrm{mg}$ of condensate/cigarette when compared with normal-alkaloid types but the condensate : nicotine ratio increased greatly.

The ratio of condensate : nicotine was lowered when lines high in nicotine were produced. In one test reported, the ratio of condensate ; nicotine ranged from 5.3 (TI 717) to 75.0 for a low-nicotine line. $N$. rustica had higher nicotine than $N$. tabacum cultivars and a lower condensate : nicotine ratio. The gene(s) responsible for the production of nicotine in $N$. rustica were transferred into $N$. tabacum and some of the derived lines had a nicotine content about $1 \%$ higher than SC 58 , the highest-nicotine cultivar, or flue-cured tobacco available. The condensate delivery / $g$ of tobacco smoked was lower for these lines when compared with SC 58. All of the lines tested gave a condensate : nicotine ratio lower than SC 58. The data showed that condensate deliveries from tobaccos vary with the environment, cultural practices and the weather conditions under which the tobacco is produced. To make progress in breeding for lower condensate delivery in tobacco, it is necessary to assay large numbers of samples and methods for doing this were discussed. To breed low-condensate delivery lines with good smoking flavor, it will be necessary, simultaneously, to select for certain flavor compounds. More research is needed on flavor chemicals of tobacco and their relationship to condensate.

\section{ZUSAMMENFASSUNG}

Die sich beim Abrauchen von Cigaretten bildende Kondensatmenge kann vom Cigarettenhersteller auf verschiedene Weise verringert werden. Es können aber auch Tabaklinien oder -sorten mit Blattgut gezüidtet werden, das bei der Pyrolyse nach der Trodknung weniger Rauchkondensat entstehen läßt. Da zwischen dem Kondensatund dem Nikotingehalt des Rauches ein Zusammenhang zu bestehen scheint, ist für die Züchtung von Tabaklinien mit geringer Kondensatbildung das $z$ wischen diesen beiden Komponenten bestehende Mengenverhältnis von Bedeutung. Die Autoren untersuchten experimentell, in welchem Maße die Kondensatmenge des Cigarettenrauches durch genetische Charakteristika des Tabaks beeinflußt werden kann. Im allgemeinen zeigte ein Vergleich der in den verschiedenen Tabakgrundtypen möglichen Kondensatausbeuten, daß Burley-Tabak höhere Kondensatwerte hatte als dunkle "fire-cured ${ }^{\alpha}$-, dunkle "air-cured ${ }^{*}$-, „flue-cured ${ }^{*}$ - und Maryland-Tabake. Bei der Selektion von Genotypen zum Zwed der Züchtung von Tabaksorten mit verminderten Kondensatwerten ist die Kondensatmenge je Gramm verbrannten Tabaks ein besserer Gradmesser als die Kondensatmenge je Cigarette. Bei der Untersuchung von Tabaken mit niedrigem Alkaloidgehalt wurde beobachtet, $\mathrm{da} \beta$ eine Verminderung des Gehaltes an Gesamtalkaloiden im Tabak zu einem nur unerheblichen Rüdkgang der Kondensatausbeute führte. Im Vergleich zu Tabaksorten mit normalem Alkaloidgehalt belief sich dieser Rüdkgang im Durchschnitt auf etwa $4 \mathrm{mg}$ Kondensat je Cigarette, wobei das Verhältnis zwischen Kondensat- und Nikotinmenge jedoch erheblich anstieg.

Bei Zuchtlinien mit hohem Nikotingehalt zeigte sich ein Rüdkgang des Kondensat/Nikotin-Verhältnisses. Dieser Zahlenwert lag in einem Versuch zwishen 5,3 (TI 717) und 75,0 bei einer Linie mit niedrigem Nikotingehalt. Nicotiana rustica hatte höhere Nikotinwerte und ein niedrigeres Kondensat/Nikotin-Verhältnis als Nicotiana tabacum. Das Gen bzw. die Gene, die für die Nikotinbildung in $N$. rustica verantwortlich sind, wurden auf $N$. tabacum übertragen mit dem Ergebnis, daß einige der daraus entstandenen linien einen um etwa $1 \%$ höheren Nikotingehalt hatten als SC-58-Tabak, die Sorte mit dem höchsten Nikotingehalt, oder als vergleidhbarer „fluecured"-Tabak. Im Vergleich zum SC-58-Tabak war bei allen diesen Linien die Kondensatmenge je Gramm verbrannten Tabaks und das Kondensat/Nikotin-Verhältnis niedriger. Die Ergebnisse zeigen, daß die Kondensatausbeute von Tabaken je nach den angewandten Anbauverfahren und den während des Wachstums herrschenden Umweltbedingungen und Witterungsverhältnissen verschieden ist. Zur Erzielung von Fortschritten bei der Züchtung von Tabak mit geringer Kondensatbildung ist die Untersuchung einer großen Anzahl von Proben erforderlich; möglidhe Untersuchungsmethoden werden diskutiert. Um zusätzlich ein gutes Raucharoma solcher 'Tabake zu erhalten, ist es notwendig, auch nach bestimmten Aromasubstanzen zu selektieren. Die Aromaverbindungen des Tabaks und deren Verhältnis zum Rauchkondensat müssen noch mehr erforscht werden. 
Les quantités de condensats se constituant lors du fumage, peuvent être réduites de différentes manières par les fabricants. Mais on peut cultiver des lignées et types de tabac présentant des feuilles, qui une fois sèches, donnent moins de condensats lors d'une pyrolyse. Comme il semble exister une corrélation entre la teneur en nicotine et la formation de condensats dans la fumée, le rapport condensat/nicotine est important pour la culture de lignées de tabac présentant de plus petites quantités de condensat. Les auteurs ont cherché à déterminer de manière expérimentale dans quelle mesure la quantité de condensat contenue dans la fumée de cigarettes peut être influencée par les caractéristiques génétiques du tabac. Une comparaison entre les différents types de tabac a montré que le tabac Burley présentait de plus fortes quantités de condensat que, par ordre décroissant, les tabacs *fire-cured * noir, *air-cured * noir, *flue-cured* et du Maryland. Pour la sélection des génotypes en vue de la culture de tabacs à teneur en condensat réduite, la quantité de condensat par gramme de tabac brûlé est un meilleur indice de référence que la quantité de condensat par cigarette. Lors de l'étude de tabacs $\$$ plus faible teneur d'alcaloïde, on a constaté qu'une réduction de leur teneur en alcaloīdes totaux n'aboutit qu'à une baisse insignifiante de la production de condensat. Par comparaison avec les types de tabac $d$ teneur en alcaloïde normale, cette baisse s'élevait en moyenne à $4 \mathrm{mg}$ de condensat par cigarette; toutefois, le rapport condensat/ nicotine a augmenté considérablement.

Le rapport condensat/nicotine s'est révélé plus bas pour les lignées à haute teneur en nicotine. Dans l'un des tests, ce rapport s'est situé entre 5,3 ('TI 717 ) et 75,0 pour une lignée à faible teneur en nicotine. Le type Nicotiana rustica a présenté une plus forte teneur en nicotine et un plus faible rapport condensat/nicotine que le type Nicotiana tabacum. Le gène ou les gènes responsables de la constitution de la nicotine dans le $N$. rustica ont été transférés sur le $N$. tabacum, ceci ayant pour conséquence une augmentation de $1 \%$ de la teneur en nicotine de certaines lignées ainsi obtenues, par rapport au tabac SC58, sorte ayant la plus forte teneur en nicotine, ou au tabac *flue-cured qui s'en approche. Pour toutes ces lignées les rapports condensat $/ g$ de tabac brôlé et condensat/nicotine étaient inférieurs à ceux constatés sur le SC58. Les résultats de l'étude font également apparaître que la production de condensat dans les tabacs varie selon les modes culturaux appliqués et selon I'environnement et le climat. Si l'on veut progresser dans la culture de tabac présentant une plus faible formation de condensat, il est indispensable de procéder à l'étude d'un grand nombre d'échantillons. Les méthodes possibles sont discutées. Si l'on désire en outre que ces tabacs aient une fumée de bonne qualité aromatique, il est nécessaire de les sélectionner d'après leurs constituants aromatiques. Il conviendra d'approfondir encore l'étude des substances aromatiques du tabac ainsi que leurs relations avec le condensat.
1. Chaplin, J. F.: Comparison of Type 32 and fluecured tobacco cultivars produced under flue-cured culture when air- and flue-cured; Tob. Sci. 19 (1975) 112-114.

2. Chaplin, J. F., and W. W. Weeks: Association between percent total alkaloids and other traits in flue-cured tobacco; Crop Sci. 16 (1976) 416-418.

3. Davis, D. L., G. B. Collins and P. D. Legg: Factors influencing tobacco tar levels; 92nd Annual Report of the Kentudsy Agricultural Experiment Station, 1979, 55-56.

4. Griffith, R. B.: The rapid determination of total alkaloids by steam distillation; Tob. Sci. 1 (1957) 130-137.

5. Legg, P. D., and J. F. Chaplin: Genetic diversity in Burley and flue-cured tobacco for smoke constituents; Crop Sci. 21 (1981) 692-695.

6. Long, T. M., and W. L. Wilson: A method for the prediction of smoke particulate matter yield from ground tobacco analysis; Tob. Sci. 22 (1978) 81-83.

7. Matzinger, D. F., and E. A. Wernsman: Inheritance and relationships among plant haracters and smoke constituents in flue-cured tobacco; Proc. 5th Int. Tob. Scientific Congr., Hamburg, 1970, 11-18.

8. Matzinger, D. F., E.A. Wernsman and W.W. Weeks: Genetic modification of total particulate matter in tobacco smoke; Tob Sci. 22 (1978) 138-140.

9. Pillsbury, H. C., C. C. Bright, K. J. O'Connor and R. W. Irish: 'Tar and nicotine in cigarette smoke; J. Assoc. Off. Anal. Chem. 52 (1969) 458-462.

10. Randolph, H. R.: A gas chromatographic determination of nicotine in an isopropyl alcohol extract of smoke particulate matter; Tob. Sci. 18 (1974) 133135.

11. Russell, M. A. H.: Smoking problems - An overview; National Institute on Drug Abuse Research Monograph 17 (Research on smoking behavior), 1979, $13-34$.

12. Watson, D. C., R. W. Hale and H. R. Randolph: Automation of the gas dhromatographic analysis for water in smoke particulate matter; J. Chromatogr. Sci. 8 (1970) 143-146.

13. Wernsman, E. A., D. F.Matzinger and W. W. Weeks: Potential for particulate -matter reduction through tobacco genetics and cultural modifications; Proc. of Amer. Chem. Soc. Symposium on recent advances in the chemical composition of tobacco and tobacco smoke, the 173rd Amer. Chem. Soc. Meeting, New Orleans, La., 1977, 340-364.

14. Williamson, R. E., and J. F. Chaplin: Estimation of tar in tobacco by multiple regression techniques; Agron. Abstr. 64 (1976) 90-91.

Autbors' address:

Tobacco Research Laboratory,

USDA-ARS-Southern Region,

Route 2, Box $16 \mathrm{G}$,

Oxford, North Carolina, 27565. 